\title{
The Mediating Effects of Brand Association, Brand Loyalty, Brand Image and Perceived Quality on Brand Equity
}

\author{
Erfan Severi ${ }^{1} \&$ Kwek Choon Ling ${ }^{1}$ \\ ${ }^{1}$ Faculty of Business and Information Science, UCSI University, Kuala Lumpur, Malaysia \\ Correspondence: Kwek Choon Ling, Faculty of Business and Information Science, UCSI University, No.1, Jalan \\ Menara Gading, UCSI Heights, 56000 Kuala Lumpur, Malaysia. Tel: 60-16-688-6248. E-mail: \\ kwekcl@ucsi.edu.my
}

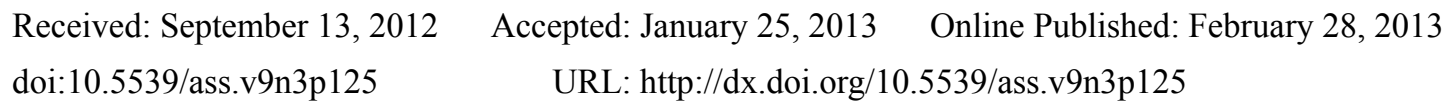

\begin{abstract}
According to Marketing Science Institute (2002), one of the major objectives of marketing research is to assess the strength of brand equity. It is imperative to acknowledge that brand equity is an inseparable part of marketing and essential to the companies to create core-competencies and build strong brand experience that will impact the consumer decision making process (Norjaya Mohd. Yasin \& Abdul Rahman Zahari, 2011). The aim of this study is to find out the indirect relationship amongst the brand equity dimensions on brand equity. For the purpose of this study, brand equity dimensions include brand association, brand awareness, brand loyalty, perceived quality and brand image. In this study, a sum of 300 usable questionnaires were gathered. The result indicates a mediating relationship amongst the dimensions of brand equity on brand equity.
\end{abstract}

Keywords: brand awareness, brand association, brand loyalty, brand image, perceived quality, brand equity

\section{Introduction}

One of the most essential topics in marketing management is the subject of brand equity. Initially brand equity was recognized by Farquhar (1989, p. 24), he stated that brand equity brought added value to the product. Brand equity is often created by products or services that bring value directly or indirectly (Kapferer, 2005 and Keller, 2003). Brand equity has been studied in two different perspectives by academicians: financial perspective and customer perspective. From the financial perspective, brand equity is evaluated according to the market value of a company's asset (Farquhar et al. 1991; Simon and Sullivan 1990). In referring to the customer perspective, brand equity is appraised according to the consumer's reaction to a brand name (Keller, 1993; Shocker \& Weitz, 1994). This research will concentrate on the customer point of view or perception to evaluate brand equity. Customer based brand equity is often divided into two categories, namely: consumer behaviour (Farquhar, 1989) and consumer perception (Mahajan et al., 1991). Based on the Mahajan et al. (1991) finding, consumer perception level can be used to evaluate customer-based brand equity. Whereas Farquhar (1989) argues that the brand equity can change the consumer attitude towards a product. Meanwhile, Keller (1993, 2003) states that brand knowledge is a mixture between brand image and brand awareness. Blackston (1995) has claimed that the definition of brand should consist of objective brand and subjective brand, which contain personality characteristic, brand image and brand attitude respectively. While Prasad and Dev (2000) suggest that in the process of evaluating brand equity, brand performance and brand awareness must be considered. Furthermore, Aaker $(1991,1996)$ suggests to incorporate perceived quality, brand awareness, brand association, and brand loyalty in the process of evaluating the degree of brand equity. As a result of the disagreement in the researches in related to the dimensions of brand equity, the purpose of this study is to identify the dimensions of brand equity and also their mediating relationship with brand equity.

\section{Literature Review}

\subsection{Brand Equity}

Brand equity can be defined as "the marketing and financial values linked with a brand's strength in the market, including actual proprietary brand assets, brand name awareness, brand loyalty, perceived brand quality, and brand associations" (Pride \& Ferrell, 2003, p. 299). According to Lassar, Mittal and Arun (1995), the existing extent literature has evaluated the brand equity from two different point of view; financial perspective and 
customer perspective. Financial perspective is usually referred to the company's brand value. While, the customer perspective appraises brand equity based on the customers' perceived brand value from the anchor of marketing decision making (Kim, Kim, and An 2003). Table 1 shows the main concepts of brand equity based on the extant literature review. This paper will adopt the idea of customer perspective of brand equity from Aaker (1991). Aaker (1996) considers brand equity as an aggregate of assets and liabilities. There are five different dimensions that can create the value of brand equity, namely; brand awareness, perceived quality, brand loyalty, brand association and proprietary brand assets (Aaker, 1996).

Table 1. The main concepts of brand equity

\begin{tabular}{ll}
\hline $\begin{array}{l}\text { Major } \\
\text { Contributors }\end{array}$ & Concepts of Brand Equity \\
\hline $\begin{array}{l}\text { Mahajan et al. } \\
(1994)\end{array}$ & Customer based Brand equity can be evaluated by the level of customer's understanding. \\
Farquhar (1989) & $\begin{array}{l}\text { Brand equity can be changed via the changes in consumers' thoughts as they are buying a } \\
\text { particular product. }\end{array}$ \\
Aaker (1991) & $\begin{array}{l}\text { Brand equity can be evaluated through brand loyalty, brand association, brand awareness } \\
\text { and perceived quality. }\end{array}$ \\
Keller (1993) & $\begin{array}{l}\text { Basically, there are two methods to evaluate customer based brand equity (direct \& indirect) } \\
\text { by stressing on two elements: brand image and brand awareness. }\end{array}$
\end{tabular}

Source: Develop for this research

The strength of brand could be traced from customer's perception and understanding about what they have gained, observed, sensed and heard regarding a brand as a consequence of customer involvement with a particular brand in the past (Keller, 2003). The value of brand equity can be significant when the brand has meaning to the individual and vice versa (Keller, 1993; Cobb-Walgren et al., 1995; Rio et al., 2001). For that reason, a number of researchers have built up conceptualization of brand equity based on five factors, for instance, value, performance, social image, attachment and trustworthiness (Lassar et al., 1995). Whereas, Aaker and Joachimsthaler (2000) have defined brand equity in various concepts which namely are; brand awareness, brand association, brand loyalty and perceived quality. Other scholars also argue that the brand equity is a multifactor structure that contains brand loyalty, brand awareness, brand knowledge, customer satisfaction, perceived equity, brand associations, and other proprietary assets (Aaker, 1991, 1996; Blackston, 1995; Cobb-Walgren et al., 1995). Further research is more inclined to consider brand equity and other brand assets, such as brand knowledge, brand awareness, brand image, brand loyalty, perceived quality, as inseparable parts of brand equity, yet independent (Keller, 1993; Kirmani \& Zeithaml, 1993).

This study will discuss the dimensions of brand equity as according to the theories of brand equity found by both authors namely: Aaker and Joachimsthaler (2000) and Keller (2003). The dimensions of brand equity being discussed in this paper consist of brand association, brand awareness, perceived quality, brand loyalty and brand image.

\subsubsection{Brand Awareness}

Brand awareness is a key and essential element of brand equity which is often overlooked (Aaker, 1996), and it is a prevalent selecting factor among customers (Cobb-Walgren et al., 1995). Aaker (1996) defines brand awareness as the durability of a brand that embedded in the customer memory. Therefore, brand awareness will be created by ongoing visibility, enhancing familiarity and powerful associations with related offerings and buying experiences (Keller, 1998). Keller $(1993,1998)$ further argues that brand awareness could influence customer decision making in buying goods via strong brand association. Pitta and Katsanis (1995) have argued that there is an inter-relationship between brand awareness and brand association by asserting that the brand awareness of a product can be produced in the consumer's mind prior to brand association of the product is built and embedded in the consumer's memory. Atigan et al. (2005) and Pappu (2005) have also pointed out the correlation between brand association and brand awareness.

\subsubsection{Brand Association}

Aaker (1991) believes that brand association and brand equity are strongly interrelated to each other because brand 
association enhances the memorable of a particular brand. According to Keller (1998), brand association can be created via the association with attitudes, attributes and benefits respectively. Brand association also acts as an information collecting tool (van Osselaer \& Janiszewski, 2001) to execute brand differentiation and brand extension (Aaker, 1996). James (2005) also discusses that highly effective association helps to boost brand and equity. In addition, Yoo et al. (2000) and Atilgan et al. (2005) have stated that strong brand association leads to higher brand loyalty.

\subsubsection{Brand Loyalty}

Aaker (1991) defines brand loyalty as symbolizes a constructive mind set toward brand that leading to constant purchasing of the brand over time. Aaker (1991) also argues that brand loyalty is an essential element when it comes to evaluate a brand in terms of value because loyalty can generate profit. According to Assael (1992, p.87-89) and Samuelsen and Sanvik (1997, p. 1123-1128), there are two approaches being used to understand the brand loyalty that have completely outclassed in the marketing literature. The first approach in marketing literature is behavioural approach to brand loyalty in which the advocators believe that constant purchasing of one brand over time is an indicator of brand loyalty. The second approach in the marketing literature is cognitive approach to brand loyalty in which the advocators argue that behaviour solely does not reflect brand loyalty. According to Yoo (2000), brand loyalty has the power to impact on customer decision to purchase the same product or brand and decline to shift to competitors' brands. As a result, Yoo (2000) concludes that brand loyalty is the core of brand's value. In addition, Strategic Marketing and Research Techniques (2008) discover that there is a strong positive relationship between customer loyalty and brand image.

\subsubsection{Brand Image}

Brand image could be defined as a brand that is brought to the consumer's mind by the brand association (Keller, 1993). Brand image can be also defined as consumer's thoughts and feelings about the brand (Roy and Banerjee, 2007). Aaker (1991) asserts that brand image could be a set of association which is significant to the consumers. Based on Bearden and Etzel (1982) as well as Park and Arinivasan (1994) arguments, brand image is closely related to the uniqueness of a particular product classification. According to Hsieh and Li (2008), strong brand image does create a superior brand messages of a particular brand over the rivalry brand. Consequently, customer's behaviour will be affected and determined by brand image (Burmann et al., 2008). Consumers employ a product's brand image in deriving overall perceptions of the specified product, a product with higher brand image may be inferred by consumers as product of superior quality and value (Richardson et al. 1994). Furthermore, Jacoby et al. (1971) conduct an experiment research and have discovered that consumers' perception of quality and value are significantly affected by brand image.

\subsubsection{Perceived Quality}

According to Aaker (1996), one of the main elements of brand equity is perceived quality and perceived quality itself is an essential part of study in evaluating brand equity. According to Aaker (1991, p. 85-86), perceived quality can be defined as the overall perception of customers about brilliance and quality of products or services in comparing with the rivalry offering. Zeithaml (1988) and Erenkol and Duygun (2010) state that quality of product is different from perceived quality because the perceived quality is the buyer's subjective appraisal of the product. Therefore, perceived quality cannot necessarily be fairly determined because perceived quality in itself is a summary construct (Aaker, 1991, p. 85-86). Zeithaml (1988) asserts that perceived quality can act as a key influencing factor in determining consumer's choices. According to Motameni and Shahrokhi (1998) and Yoo et al. (2000), perceived quality is positively related to the brand equity.

\subsection{Mediated Hypotheses}

\subsubsection{Relationship among Brand Awareness, Brand Equity and Brand Association}

Keller $(1993,1998)$ argues that brand awareness does create impact on buyer decision making process via brand association that embedded in the buyer memory. There is a correlation between brand awareness and brand association (Atigan et al. 2005; Pappu, 2005; Pappu \& Katsanis, 1995). Brand awareness is the first and fundamental attribute of customer brand equity (Aaker, 1991; Aaker, 1996; Tong \& Hawley, 2009). Brand awareness precedes the construction of brand equity in the consumer mind set (Huang \& Sarigöllü, 2011); it affects customer's perception and attitudes. Therefore, Aaker (1996) asserts that in order to assess brand equity, brand awareness has to be taken into account. Aaker (1991) believes that brand association and brand equity are strongly interrelated to each other because brand association is an element that helps a brand to be remembered. High brand awareness produces strong brand association and in turn strong brand association creates positive impact on brand equity because brand association is viewed as "a sign of quality and commitment", leading customers to 
familiarize purchasers with a brand, as well as "helping them consider it at the point of purchase" (Aaker, 1991; Tong \& Hawley, 2009; Marinova et al., 2011; Yoo et al., 2000). Based on the aforementioned, theoretical interrelationship among brand awareness, brand association and brand equity has been proved, but there is a lack of study to evaluate the mediating relationship among these three constructs. Therefore, this paper tries to evaluate the relationship between brand awareness and brand equity mediated by brand association via hypothesis 1 .

H1: The relationship between brand awareness and brand equity is mediated by brand association

\subsubsection{Relationship among Brand Association, Brand Equity and Brand Loyalty}

Brand association is an element that helps a brand to be remembered (Aaker, 1991). Aaker defines brand loyalty as symbolizes a constructive mind set toward brand that leading to constant purchasing of the brand over time. Furthermore, research done by Atilgan et al. (2005) and Yoo et al. (2000) discovers that if customers have more positive association toward a brand, they would be more loyalty toward a brand and the other way round. Aaker (1991) believes that brand association and brand equity are strongly and positively interrelated to each other, since it is viewed as "a sign of quality and commitment", leading customers to familiarize purchasers with a brand (Aaker, 1991; Tong \& Hawley, 2009; Marinova et al., 2011; Yoo et al., 2000). Oliver (1979, p. 392) defines brand equity as "a deeply held commitment to rebury or re-patronize a preferred product or service consistently in the future, deposit situation influences and marketing efforts having the potential to cause switching behavior". According to Travis (2000), the ultimate objective and meaning of brand equity is to build brand loyalty. At the meanwhile, theoretical interrelationship among brand association, brand loyalty and brand equity has been proved, but there is a lack of mediating relationship among these three constructs. Therefore, this paper tries to evaluate the relationship between brand association and brand equity mediated by brand loyalty via hypothesis 2 .

H2: The relationship between brand association and brand equity is mediated by brand loyalty

\subsubsection{Relationship among Brand Loyalty, Brand Equity and Brand Image}

According to Yoo (2000), brand loyalty has the power to impact on customer decision to purchase the same product or brand and decline to shift to competitive brands. Brand image can be defined as consumer's thoughts and feelings about the brand (Roy \& Banerjee, 2007). Yoo (2000) argues that there is a positive relationship between brand loyalty and brand image. According to Marshall (2010), brand loyalty is a thought that firms emphasizes, while it may create or sustain a customers' patronage over the long-term, thereby increases brand equity. Thus, brand loyalty is located in the heart of brand equity. Gladden and Milne (2004) believe that one of the components of brand equity is brand image. Based on the aforementioned, theoretical interrelationship among brand loyalty, brand image and brand equity has been proved but there is a lack of study to evaluate the mediating relationship among these three constructs. Thus, this paper tries to evaluate the relationship between brand loyalty and brand equity mediated by brand image via hypothesis 3 .

H3: The relationship between brand loyalty and brand equity is mediated by brand image

\subsubsection{Relationship among Brand Image, Brand Equity and Perceived Quality}

According to Richardson et al. (1994), consumers employ a product's brand image in deriving overall perceptions of the specified product. Consumers may infer a product with higher brand image as product of superior quality and value (Richardson et al., 1994). Jacoby et al. (1971) conduct an experiment research have discovered that consumers' perception of quality and value are significantly affected by brand image. Similar conclusions are derived by Shimp and Bearden (1982) as well as Rao and Monroe (1989), their studies support the notion that brand image, in many occasions, served as consumers quick reference, or "short-hand" of quality and value representation. Kotler and Armstrong (1996) mention that brand image is used by consumers to evaluate the perceived quality of products. Richardson et al. (1994) conclude that there is a positive relationship between brand image and perceived quality. Goldden and Milne (2004) assert that brand image is part of the brand equity, by arguing that the consumer perceptions of the brand image will create the impact toward the brand equity of a particular product or service offered. Aaker (1996) has stated that one of the key elements of brand equity is perceived quality and it is the core construct in the research to appraise brand equity. Furthermore, Yoo (2000) mentions that brand equity will be increased with the help of promoting positive perceived quality; perceived quality is parts of brand value that leads consumers to select a particular brand rather than another competing brand. Based on the aforementioned, theoretical interrelationship among perceived quality, brand image and brand equity has been proved, but there is a lack of study to evaluate the mediating relationship among these three constructs. Therefore, this paper tries to evaluate the relationship between brand image and brand equity mediated by perceived quality via hypothesis 4 .

H4: The relationship between brand image and brand equity is mediated by perceived quality 


\subsection{Proposed Conceptual Framework}

The tested conceptual framework was illustrated in Figure 1 in which all the mediating relationships among the constructs will be carried out in the hypothesized testing.

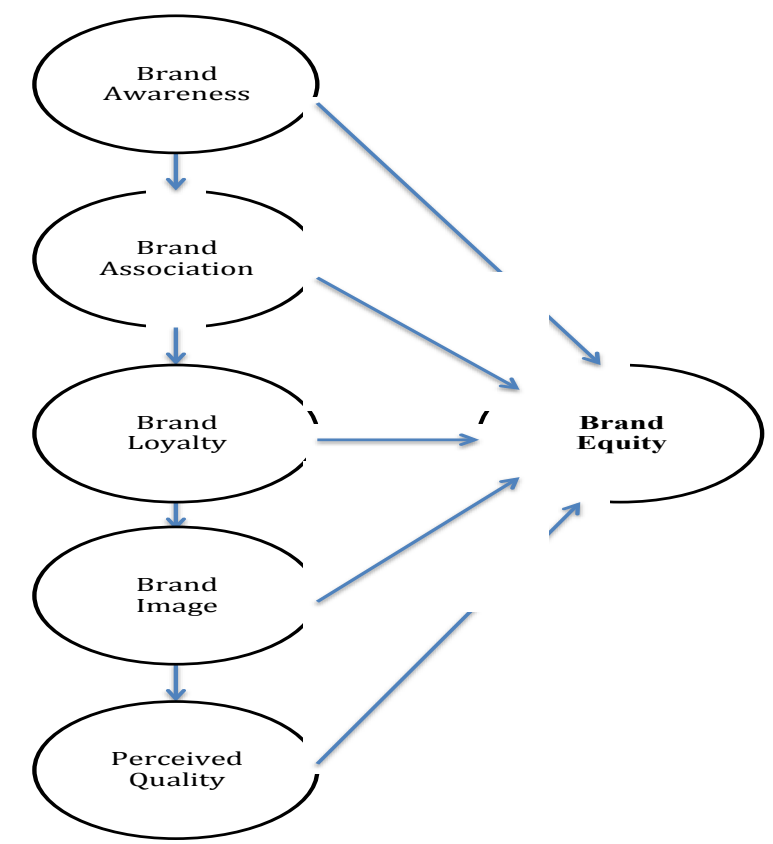

Figure 1. Proposed conceptual framework

\section{Methodology}

\subsection{Research Design}

Descriptive research design was adopted in this study to conclude the inferences derived from the hypothesized testing (Malhotra, 2004).

\subsection{Questionnaire Design}

Basically the questionnaire was designed and separated into two parts, part 1 and part 2. Part 1 consists of measuring brand equity elements, which include; brand awareness, brand association, brand loyalty, brand image and perceived quality. In part 2, the questionnaire data and information that related to the respondents were elaborated, such as gender, nationality, age, marital status and educational qualification. Items that being used for measuring Brand Awareness were adopted from Atilgan et al. (2005) and Yoo et al. (2000). Items that being used for measuring Brand Association and Brand Loyalty were adopted from Kim and Kim (2005) and Yoo et al. (2000). Lastly, the measurement items of Brand Image and Perceived Quality were adopted from Kim and Kim (2005). For the purpose of conducting this research, the researchers has chosen five point likert scales from "Strongly disagree" (1) to "Strongly agree" (5) for all the tested constructs (Kim \& Kim, 2005).

\subsection{Sampling}

In this research, the target population covers all the existing full time business students who are study in one of the private universities in Malaysia. 330 potential respondents were used as a sampling size and in order to choose the potential respondents in this survey convenience sampling technique has been adopted.

\subsection{Administration of Survey}

In this research, the drop-off survey techniques have been used. The copies of self-administered survey questionnaires have been given to the respondents in order to make sure the confidentiality and privacy aspects of participants in the survey. Before the actual survey being conducted, a pilot test with 30 potential respondents was carried out. The pilot test was carried out with the purpose to ensure the reliability of the scale measurement as well as the quality of the questionnaire. Based on the feedback from the pilot test study, a final set of questionnaire was produced. Out of 330 questionnaires that have been distributed in the actual survey, 300 questionnaires were gathered. A part from 30 questionnaires that were unfinished for the reason of either the respondents were not willing to cooperate or they did not take the survey seriously. However, the rest of the questionnaires (300) have been used (91.6 percent) for data analysis using SPSS software (version 20). 


\section{Research Results}

\subsection{Demographic Profile Analysis}

Respondents of this survey consist of 50 percent male and 50 percent female, which means the participants were equally chosen from both genders. The age trend of the participants is as follows:

Between the age of 26-30 years old group has the highest respondents ( 42.3 percent) that is followed by the age group of 21-25 years old (38.7 percent), 31-35 (14 percent), 20 years old or less (3.3 percent) and finally the age group of 30-40 years old (1.4 percent) had the lowest participant amongst all the age groups participated in this survey. The respondents' highest education levels were majority in Master's Degree (51 percent), following by Bachelor's Degree (41.7 percent) and Diploma (4.7 percent).

\subsection{Reliability Test}

According to Cavana et al. (2001), reliability test can be used as a measure that signals the consistency and stability of the instruments used in the survey when repeated measurements are made. A well known approach to measure reliability is to use the Cronbach alpha. The value of Cronbach alpha with the range of greater than 0.70 is considered acceptable and good (Cavana et al., 2001). Results from the Table 2 point out the Cronbach alpha for the six tested constructs were well above 0.70 . Based on the finding, Cronbach alpha for the construct ranged from lowest of 0.780 (brand image) to 0.914 (brand awareness). In conclusion, the outcome concluded that the measurement scales of the constructs were stable and consistent in measuring the constructs.

Table 2. Reliability of the Constructs

\begin{tabular}{ll}
\hline Constructs & Composite Reliability \\
\hline Brand Awareness & 0.914 \\
Brand Association & 0.795 \\
Brand Loyalty & 0.821 \\
Brand Image & 0.780 \\
Perceived quality & 0.838 \\
Brand Equity & 0.889 \\
\hline
\end{tabular}

Source: Developed for this research

\subsection{Validity Test}

Cavana et al. (2001) state that in order to measure validity, construct validity has to be utilized and the measurement for the validity is factor analysis. Table 3 shows the outcome of the factor analysis. The value of Kaiser-Mayer-Olkin (KMO) was 0.850 (between 0.5 and 1.0) which means that the sample size is big enough to conduct factor analysis. The statistical test for Bartlett test of sphericity was significant $(p=0.0001$; d.f. $=351)$ for all the correlations within a correlation matrix (at least for some of the constructs). With reference to the principle components analysis and VARIMAX process in the orthogonal rotation, the outcomes showed that the Eigenvalues for all the constructs were higher than 1.0, ranging from the lowest of 1. 544 (Brand Image) to the highest of 7.971 (Brand Awareness). In the case of convergent validity, the factor loadings for all items within a construct showed in Table 3 were more than 0.50. Based on the results indicated in Table 3, discriminant validity point out that all items were assigned according to the different constructs. Hence, the items were not overlapping and they supported respective constructs. 
Table 3. Factors identified by principal components factor analysis

\begin{tabular}{|c|c|c|c|c|c|}
\hline $\begin{array}{l}\text { Factor's } \\
\text { Name }\end{array}$ & Variable & $\begin{array}{l}\text { Factor } \\
\text { Loading }\end{array}$ & $\begin{array}{l}\text { Eigen- } \\
\text { value }\end{array}$ & $\begin{array}{l}\text { Percentage } \\
\text { of Variance } \\
\text { Explained }\end{array}$ & $\begin{array}{l}\text { Cronbach's } \\
\text { Reliability } \\
\text { Coefficients }\end{array}$ \\
\hline \multirow[t]{5}{*}{$\begin{array}{l}\text { Brand } \\
\text { Awareness }\end{array}$} & $\begin{array}{l}\text { I aware this particular product/brand that appeared in the } \\
\text { social media. }\end{array}$ & 0.872 & 7.971 & 14.80 & 0.914 \\
\hline & $\begin{array}{l}\text { I can recognize this particular product/brand in } \\
\text { comparison with the other competing product/brand that } \\
\text { appeared in the social media. }\end{array}$ & 0.851 & & & \\
\hline & I know how this particular product/brand looks like. & 0.871 & & & \\
\hline & $\begin{array}{l}\text { Some characteristics of the particular product/brand that } \\
\text { appeared in the social media come to my mind quickly. }\end{array}$ & 0.872 & & & \\
\hline & $\begin{array}{l}\text { I can quickly recall symbol or logo of the particular } \\
\text { product/brand that appeared in the social media. }\end{array}$ & 0.770 & & & \\
\hline \multirow[t]{5}{*}{$\begin{array}{l}\text { Brand } \\
\text { Loyalty }\end{array}$} & $\begin{array}{l}\text { I regularly refer this particular product/brand through the } \\
\text { social media. }\end{array}$ & 0.646 & 2.598 & 11.365 & 0.821 \\
\hline & $\begin{array}{l}\text { I usually use this product/brand as my first choice in } \\
\text { comparison with the other product/brand. }\end{array}$ & 0.736 & & & \\
\hline & $\begin{array}{l}\text { I would recommend this product/brand to others through } \\
\text { the social media. }\end{array}$ & 0.563 & & & \\
\hline & $\begin{array}{l}\text { I will not switch to another product/brand that appeared } \\
\text { in the social media next time. }\end{array}$ & 0.801 & & & \\
\hline & $\begin{array}{l}\text { I am satisfied with product/brand that appeared in the } \\
\text { social media }\end{array}$ & 0.823 & & & \\
\hline \multirow[t]{5}{*}{$\begin{array}{l}\text { Brand } \\
\text { Association }\end{array}$} & $\begin{array}{l}\text { This particular product/brand that appeared in the social } \\
\text { media has its own personality. }\end{array}$ & 0.873 & 1.928 & 11.035 & 0.795 \\
\hline & $\begin{array}{l}\text { This particular product/brand is different in comparison } \\
\text { with the other competing product/brand that appeared in } \\
\text { the social media. }\end{array}$ & 0.852 & & & \\
\hline & $\begin{array}{l}\text { I trust the company who owns the particular } \\
\text { product/brand that appeared in the social media. }\end{array}$ & 0.871 & & & \\
\hline & $\begin{array}{l}\text { This particular product/brand that appeared in the social } \\
\text { media is familiar to me. }\end{array}$ & 0.874 & & & \\
\hline & $\begin{array}{l}\text { There are reasons to buy this particular product/brand } \\
\text { over the competing product/brand that appeared in the } \\
\text { social media. }\end{array}$ & 0.755 & & & \\
\hline \multirow[t]{4}{*}{$\begin{array}{l}\text { Perceived } \\
\text { Quality }\end{array}$} & $\begin{array}{l}\text { The Webmaster provides prompt services at the promised } \\
\text { time. }\end{array}$ & 0.782 & 1.697 & 10.054 & 0.838 \\
\hline & The Webmaster handles customer complained effectively. & 0.745 & & & \\
\hline & $\begin{array}{l}\text { The Webmaster is able to tell patrons exactly when the } \\
\text { services would be performed. }\end{array}$ & 0.783 & & & \\
\hline & The Webmaster gives individual customer attention. & 0.805 & & & \\
\hline
\end{tabular}




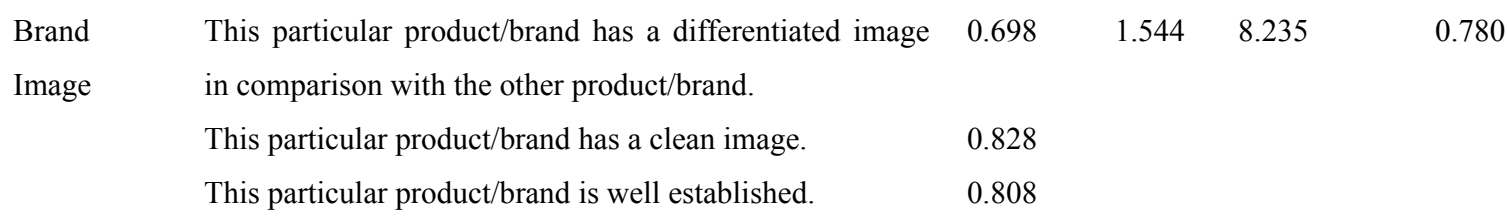

Note: KMO Measure of Sampling Adequacy $=0.850 ; \mathrm{p}=0.0001(\mathrm{p}<0.05) ; \mathrm{df}=351$

Cumulative Percentage Rotation Sums of Squared Loadings $=68.368$

Source: Developed for this research

\subsection{Mediated Regression Analysis}

Mediational analysis is used to examine how two variables precede or cause a third variable (refer to dependent variable) (Howitt and Cramer, 2011a). For the purpose of testing four hypotheses, Baron and Kenny (1986) have proposed mediated regression analysis that was used in this research (H1, H2, H3 and H4). Baron and Kenny (1986) have recommended three step process that was adopted in this research. Based on Baron and Kenny (1986) approach, there are three steps that should be considered:

1) The mediating variable is regressed on the independent variable.

2) The dependent variable is regressed on the independent variable.

3) The dependent variable is simultaneously regressed on the dependent variable and the mediating variable.

Baron and Kenny (1986, p.1177) assert that in order to establish mediation, the following conditions ought to be present: Firstly, the independent variable has to impact the mediator in the first step; secondly, the independent variable has to impact the dependent variable in the second step; and lastly, the mediator has to impact the dependent variable in the third step. Taking into account the conditions in the forecasted direction, the outcome of independent variable in step three has to be less than in step two. Tables below illustrate $\{4(a), 4(b), 4(c)$ and 4(d) $\}$ the three steps process recommended by Baron and Kenny (1986):

4.4.1 Relationships among Brand Awareness, Brand Equity and Brand Association (H1)

Table 4(a). Result of mediated multiple regression (mediator analysis) (H1)

\begin{tabular}{llll}
\hline Independent Variable & Brand Association (Mediator) & \multicolumn{2}{l}{ Brand Equity (Dependent Variable) } \\
\cline { 2 - 4 } & Model 1 & Model 2 & Model 3 \\
\hline Brand Awareness & $0.316^{*}$ & $2.237^{*}$ & $1.665^{*}$ \\
& $\left(1^{\text {st }}\right.$ equation) & $\left(2^{\text {nd }}\right.$ equation $)$ & ( $3^{\text {rd }}$ equation $)$ \\
Brand Association & & & $1.808^{*}$ \\
& & & (3 \\
& & & \\
\hline
\end{tabular}

$* \mathrm{p}<0.05$

Source: Developed for this research

According to the finding from Table 4(a), brand awareness as an independent variable significantly affected the brand association as a mediator in equation one; brand awareness as an independent variable significantly impacted the brand equity as a dependent variable in equation two; both brand awareness as an independent variable and brand association as a mediator considerably impacted the brand equity as a dependent variable. Hypothesis 1 (H1) is supported because the beta value of brand awareness in the equation three (beta $=1.665)$ is smaller than the beta value of brand awareness in the equation two (beta=2.237), diminishing by 0.572 (2.237-1.665). In conclusion, brand association does act as a mediator in mediating the relationship between brand awareness and brand equity. 
4.4.2 Relationships among Brand Association, Brand Equity and Brand Loyalty $(\mathrm{H} 2)$

Table 4(b). Result of mediated multiple regression (mediator analysis) (H2)

\begin{tabular}{llll}
\hline Independent Variable & \multicolumn{2}{l}{ Brand Loyalty (Mediator) } & \multicolumn{2}{l}{ Brand Equity (Dependent Variable) } \\
\cline { 2 - 4 } & Model 1 & Model 2 & Model 3 \\
\hline Brand Association & $0.416^{*}$ & $2.297^{*}$ & $1.587^{*}$ \\
& $\left(1^{\text {st }}\right.$ equation $)$ & $\left(2^{\text {nd }}\right.$ equation $)$ & $\left(3^{\text {rd }}\right.$ equation $)$ \\
Brand Loyalty & & & $1.704^{*}$ \\
& & & $\left(3^{\text {rd }}\right.$ equation $)$ \\
\hline
\end{tabular}

$* \mathrm{p}<0.05$

Source: Developed for this research

Based on finding in Table 4(b), brand association as an independent variable significantly affected the brand loyalty as a mediator in equation one; brand association as an independent variable considerably impacted the brand equity as a dependent variable in equation two; both brand association as an independent variable and brand loyalty as a mediator considerably impacted the brand equity as a dependent variable. Hypothesis 2 (H2) is supported because the beta value of brand association in equation three (beta=1.587) is smaller than the beta value of brand association in equation two (beta=2.297), diminishing by 0.71 (2.297-1.587). In conclusion, brand loyalty does act as a mediator in mediating the relationship between brand association and brand equity.

4.4.3 Relationships among Brand Loyalty, Brand Equity and Brand Image (H3)

Table 4(c). Result of mediated multiple regression (mediator analysis) (H3)

\begin{tabular}{llll}
\hline Independent Variable & \multicolumn{2}{l}{ Brand Image (Mediator) } & \multicolumn{2}{l}{ Brand Equity (Dependent Variable) } \\
\cline { 2 - 4 } & Model 1 & Model 2 & Model 3 \\
\hline Brand Loyalty & $0.224^{*}$ & $2.326^{*}$ & $1.903^{*}$ \\
& $\left(1^{\text {st }}\right.$ equation $)$ & $\left(2^{\text {nd }}\right.$ equation $)$ & $\left(3^{\text {rd }}\right.$ equation $)$ \\
Brand Image & & & $1.890^{*}$ \\
& & & $\left(3^{\text {rd }}\right.$ equation $)$ \\
\hline
\end{tabular}

$* \mathrm{p}<0.05$

Source: Developed for this research

According to the finding from Table 4(c), brand loyalty as an independent variable significantly affected the brand image as a mediator in equation one; brand loyalty as an independent variable significantly affected the brand equity as a dependent variable in equation two; both brand loyalty as an independent variable and brand image as a mediator considerably impacted the brand equity as a dependent variable. Hypothesis 3 (H3) is supported because the beta value of brand loyalty in equation three (beta=1.903) is smaller than the beta value of brand loyalty in equation two (beta=2.326), diminishing by 0.423 (2.326-1.903). In conclusion, brand image does act as a mediator in mediating the relationship between brand loyalty and brand equity. 
4.4.4 Relationships Among Brand Image, Brand Equity and Perceived Quality (H4)

Table 4(d). Result of mediated multiple regression (mediator analysis) (H4)

\begin{tabular}{llll}
\hline Independent Variable & Perceived Quality (Mediator) & \multicolumn{2}{l}{ Brand Equity (Dependent Variable) } \\
\cline { 2 - 4 } & Model 1 & Model 2 & Model 3 \\
\hline Brand Image & $0.374^{*}$ & $2.732^{*}$ & $2.032^{*}$ \\
& $\left(1^{\text {st }}\right.$ equation $)$ & $\left(2^{\text {nd }}\right.$ equation $)$ & $\left(3^{\text {rd }}\right.$ equation $)$ \\
Perceived Quality & & & $1.869^{*}$ \\
& & & $\left(3^{\text {rd }}\right.$ equation $)$ \\
\hline
\end{tabular}

$* \mathrm{p}<0.05$

Source: Developed for this research

According to the finding from Table 4(d), brand image as an independent variable significantly affect the perceived quality as a mediator in equation; brand image as an independent variable significantly affect the brand equity as a dependent variable in equation two; both brand image as an independent variable and perceived quality as a mediator considerably impacted the brand equity as a dependent variable. Hypothesis 4 (H4) is supported because the beta value of brand image in equation three (beta $=2.032$ ) is smaller than the beta value of brand image in equation two (beta $=2.732)$, diminishing by $0.7(2.732-2.032)$. In conclusion, perceived quality does act as a mediator in mediating the relationship between brand image and brand equity.

\section{Conclusion}

\subsection{Implications of Research Findings}

\subsubsection{Theoretical Implication}

In terms of theoretical implication, this study has concluded as follows; relationship between brand awareness and brand equity is mediated by brand association; relationship between brand association and brand equity is mediated by brand loyalty; relationship between brand loyalty and brand equity is mediated by brand image and finally relationship between brand image and brand equity is mediated by perceived quality.

\subsubsection{Managerial Implication}

The outcome of this research has given valuable feedbacks which can be used for designing different strategies to attract customers with emphasizing on brand equity of the products and services. Marketers should remember that there are some factors influence consumer's perception towards brand equity. Based on the results from this research finding, marketers should prioritize brand equity constructs as their strategy to attract potential customers because it does show significant direct and indirect relationships between the dimensions of brand equity and brand equity.

\subsection{Limitations of Research}

The outcome of this research has given valuable feedbacks to researchers. However, these outcomes were accompanied with some limitations. Cavana et al. (2001) have stated that cross-sectional data that is only able to reveal the net effect of predictor variable towards a particular criterion variable at a specific point of time. Due to the limitation of cross-sectional study, the outcomes and findings of the research are not capable to "explain why the observed patterns are there" (Easterly-Smith, Thorpe \& Lowe, 2003). Furthermore, the restriction of using convenience sampling techniques has indicated that the outcomes of this research cannot be generalized.

\subsection{Recommendation for Future Study}

As this research has encountered some limitations, a few recommendations have been suggested for further research. Psychological judgment will change over time. Therefore, cross-sectional study might not be capable to portray the experiential changes in models and the causality of the brand equity (Easterby- Smith et al., 2003). In due respect, longitudinal studies, which continually measure the same sample units of population over a period of time is recommended to be used in the future research (Burns and Bush, 2003). Furthermore, in terms of restriction of generalization, it would be suggested to use probability sampling technique in the future study for the reason of improving and enhancing the validity and generalization of these research findings. 


\section{References}

Aaker, D. A. (1991). Managing brand equity. New York: The Free Press.

Aaker, D. A. (1996). Managing brand equity: Capitalizing on the value of the brand name. New York: The Free Press.

Aaker, D. A., \& Joachimsthaler, E. (2000). Brand Leadership. New York: The Free Press

Assael, H. (1992). Consumer behavior and marketing action. Boston: PWS-Kent Publishing.

Atilgan, E., Aksoy, S., \& Akinci, S. (2005). Determinants of the brand equity: A verification approach in the beverage industry in Turkey. Marketing Intelligence \& Planning, 23(3), 237-248. http://dx.doi.org/10.1108/02634500510597283

Baron, R. M., \& Kenny, D. A. (1986). The moderator-mediator variable distinction in social psychological research: Conceptual, strategic and statistical considerations. Journal of Personality \& Social Psychology, 51, 1173-1182. http://dx.doi.org/10.1037/0022-3514.51.6.1173

Bearden, W. O., \& Etzel, M. J. (1982). Reference group influence on product and brand purchase decisions. Journal of Consumer Research, 9, 183-194. http://dx.doi.org/10.1086/208911

Blackston, M. (1995). The qualitative dimension of brand equity. Journal of Advertising Research, 35(4), 2-7.

Burmann, C., Schaefer, K., \& Maloney, P. (2008). Industry image: Its impact on the brand image of potential employees. Journal of Brand Management, 16(3), 159-176.

Cavana, R. Y., Delahaye, B. L., \& Sekaran, U. (2001). Applied business research: Qualitative and quantitative methods. Queensland: John Wiley \& Sons.

Churchill, G. A., \& Brown, T. J. (2004). Basic marketing research. Ohio: South Western.

Cobb Walgren, C. J., Ruble, C. A., \& Donthu, N. (1995). Brand equity, brand preference and purchase intention. Journal of Advertising, 24(3), 25-41.

Easterby Smith, M., Thorpe, R., \& Lowe, A. (2003). Management research: An introduction. California: SAGE Publications.

Erenkol, A. D., \& Duygun, A. (2010). Customers perceived brand equity and a research on the customers of Bellona which is a Turkish furniture brand. The Journal of American Academy of Business, 16(1).

Farquhar, P. H. (1989). Managing brand equity. Journal of Marketing Research, 1, 24-33.

Farquhar, P. H., Han, J. Y., \& Ijiri, Y. (1991). Recognizing and measuring brand assets. Marketing Science Institute. MA: Cambridge

Fiske, S. T., \& Taylor, S. E. (1995). Social cognition. New York: McGraw-Hill.

Gladden, J. M., \& Milne, G. R. (2004). Examining the importance of brand equity in professional sport. In S. Rosner, \& K. Shropshire (Eds.), The Business of Sports. Massachusetts: Jones and Bartless Publishers.

Hair, J. Jr., Wolfinbarger, M., Bush, R., \& Ortinau, D. (2009). Essentials of marketing research. Ohio: McGraw-Hill.

Howitt, D., \& Cramer, D. (2011). Introduction to SPSS statistics in psychology for version 19 and earlier (5th ed.). Essex: Pearson Education Limited.

Huang, R., \& Sarigöllü, E. (2011). How brand awareness relates to market outcome, brand equity, and the marketing mix. Journal of Business Research, 07136.

Jacoby, J., Olson, J., \& Haddock, R. (1971). Price, brand name, and product composition characteristics as determinants of perceived quality. Journal of Applied Psychology, 55(6), 570-579. http://dx.doi.org/10.1037/h0032045

James, D. (2005).Guilty through association: Brand association transfer to brand alliances. Journal of Consumer Marketing, 22(1), 14-25. http://dx.doi.org/10.1108/07363760510576518

Kapferer, J. N. (2005). The new strategic brand management. London: Kogan-Page.

Keller, K. L. (1993). Conceptualizing, measuring and managing customer based brand equity. Journal of Marketing, 57, 1-22. http://dx.doi.org/10.2307/1252054

Keller, K. L. (1998). Strategic brand management: Building, measuring and managing brand equity. London: Prentice Hall International. 
Keller, K. L. (2003). Strategic brand management: Building, measuring, and managing brand equity (2nd ed.). NJ: Prentice Hall.

Kim, H. B., \& Kim, W. G. (2005). The relationship between brand equity and firm's performance in luxury hotels and chain restaurants. Tourism Management, 26, 549-560. http://dx.doi.org/10.1016/j.tourman.2004.03.010

Kim, H. B., Kim, W. G., \& An, A. J. (2003). The effect of consumer based brand equity on firm's financial performance. Journal of Consumer Marketing, 20(4), 335-351. http://dx.doi.org/10.1108/07363760310483694

Kirmani, A., \& Zeithaml, V. (1993). Advertising, perceived quality and brand image. In D. A. Aaker, \& A. L. Biel (Eds.), Brand Equity and Advertising (pp. 143-161). Lawrence Erlbaum, Mahwah, NJ.

Kotler, P., \& Armstrong, G. (1996). Principles of marketing (7th ed.). New Jersey: Prentice-Hall International, Inc.

Lassar, W., Mittal., B., \& Arun., S. (1995). Measuring consumer based brand equity. Journal of Consumer Marketing, 12(4), 11-19. http://dx.doi.org/10.1108/07363769510095270

Mahajan, V., Rao, V. R., \& Srivastava, R. K. (1994). An approach to assess the importance of brand equity in acquisition decisions. Journal of Product Innovation Management, 11, 221-235. http://dx.doi.org/10.1016/0737-6782(94)90005-1

Malhotra, N. K. (2004). Marketing research: An applied orientation (4th ed.). New Jersey: Prentice Hall.

Marinova, S., Cui, J., Marinov, M., \& Shiu, E. (2011). Customers relationship and brand equity: A study of bank retailing in China. WBC, Poznau, 6-9.

Marketing Science Institute. (2002). Research priorities. Marketing science. Retrieved from http://www.msi.org/msi/pdf/MSI_RP04-06.pdf

Motameni, \& Shahrokhi. (1998). Brand Equity Valuation: A Global Perspective. Journal of Product and Brand Management, 7(4), 275-290. http://dx.doi.org/10.1108/10610429810229799

Oliver, R. L. (1997). Satisfaction: A behavioral perspective on the consumer. New York: McGraw-Hill.

Pappu, R. (2005). Consumer-based brand equity: Improving the measurement. Journal of Product and Brand management, 14(3), 143-154. http://dx.doi.org/10.1108/10610420510601012

Park, C. W., \& Arinivasan, V. (1994). A survey-based method for measuring and understanding brand equity and its extendibility. Journal of Marketing Research, (31), 271-288. http://dx.doi.org/10.2307/3152199

Pitta, D. A., \& Katsanis, L. P. (1995). Understanding brand equity for successful brand extension. Journal of Consumer Marketing, 12(4), 51. http://dx.doi.org/10.1108/07363769510095306

Prasad, K., \& Dev, C. S. (2000). Managing hotel brand equity: A customer-centric framework for assessing performance. Cornell Hotel and Restaurant Administration Quarterly, 41(3), 22-31. http://dx.doi.org/10.1177/001088040004100314

Pride, W. M., \& Ferrell, O. C. (2003). Marketing: concepts and strategies. Boston: MA: Houghton Mifflin Company.

Rao, A., \& Monroe, K. (1989). The effect of price, brand name, and store name on buyers' perceptions of product quality: An integrative review. Journal of Marketing Research, 26(3), 351-357. http://dx.doi.org/10.2307/3172907

Richardson, P., Dick, A., \& Jain, A. (1994). Extrinsic and intrinsic cue effects on perceptions of store brand quality. The Journal of Marketing, 58(4), 28-36. http://dx.doi.org/10.2307/1251914

Rio, A. B., Vazquez, R., \& Iglesias, V. (2001). The effects of brand associations on consumer response. Journal of Consumer Marketing, 18(5), 410-425. http://dx.doi.org/10.1108/07363760110398808

Roy, D., \& Banerjee, S. (2007). Caring strategy for integration of brand identity with brand image. International Journal of Commerce and Management, 17(1/2), 140-148. http://dx.doi.org/10.1108/10569210710776512

Samuelsen, B. M., \& Sandvik, K. (1997). The concept of customer loyalty. The 25th EMAC Conference, University of Warwick, UK.

Shimp, T. A., \& Bearden, W. O. (1982). Warranty and other extrinsic are effects on consumer's risk perceptions. Journal of Consumer Research, 9, 38-46. http://dx.doi.org/10.1086/208894

Shocker, A. D., \& Weitz, B. (1994). A perspective on brand equity principles and issues. In L. Leuthesser (Ed.), 
Report Number 88-104. Cambridge, MA: Marketing Science Institute.

Simon, C. J., \& Sullivan M. W. (1990). The measurement and determinants of brand equity: A financial approach. Working Paper, Graduate School of Business, University of Chicago.

Strategic Marketing \& Research Techniques. (1992-2008). Brand and image assessment. Retrieved from http://www.s-m-a-r- t.com/Exp_brandequity.htm

Tong, X., \& Hawley, J. M. (2009). Measuring customer-based brand equity: Empirical evidence from the sportswear market in China. Journal of Product and Brand Management, 18(4), 262-271. http://dx.doi.org/10.1108/10610420910972783

Travis, D. (2000). Emotional branding: How successful brands gain the irrational edge. Crown Publishing Group.

Van Osselaer, S. M. J., \& Janiszewski, C. (2001). Two ways of learning brand association. Journal of Consumer Research, 28, 202-223. http://dx.doi.org/10.1086/322898

Yasin, N. M., \& Zahari, A. R. (2011). Does family and viral marketing have any effect on brand equity? Journal of Contemporary Marketing Review, 1(9), 19-31.

Yoo, B., Donthu, N., \& Lee, S. (2000). An examination of selected marketing mix elements and brand equity. Journal of the Academy of Marketing Science, 28(2), 195-211. http://dx.doi.org/10.1177/0092070300282002

Zeithaml, V. (1988). Consumer perception of price, quality and the value: A mean-end and synthesis of evidence, Journal of Marketing, 52(2), 2-22. http://dx.doi.org/10.2307/1251446 